九州大学学術情報リポジトリ

Kyushu University Institutional Repository

\title{
Effects of Calcium Supplement to Purified Diets on Growth and Bone Mineralization in Juvenile Red Sea Bream and Black Sea Bream
}

Hossain M., Amzad

Laboratory of Fish Production Technology, Division of Fish Production Technology, Department of Animal and Marine Bioresource Science, Graduate School of Bioresource and Bioenvironmental Sciences, Kyushu University

Furuichi, Masayuki

Laboratory of Fish Production Technology, Division of Fish Production Technology, Department of Animal and Marine Bioresoruce Science, Faculty of Agriculture, Kyushu University

https://doi.org/10.5109/24398

出版情報: 九州大学大学院農学研究院紀要. 45 (2)，pp.481-486，2001-02-28. Kyushu University バージョン：

権利関係 : 
J. Fac. Agr., Kyushu Univ., 45 (2), 481-486 (2001)

\title{
Effects of Calcium Supplement to Purified Diets on Growth and Bone Mineralization in Juvenile Red Sea Bream and Black Sea Bream
}

\author{
M. Amzad Hossain* and Masayuki Furuichi \\ Laboratory of Fish Production Technology, Division of Fish Production Technology, \\ Department of Animal and Marine Bioresource Science, Faculty of Agriculture, \\ Kyushu University, Fukuoka 812-8581, Japan \\ (Received October 30, 2000 and accepted November 10, 2000)
}

\begin{abstract}
Juvenile red sea bream (av. body wt. $1.4 \mathrm{~g}$ ) and black sea bream (av. body wt.0.5 g) were fed two purified casein based diets containing $0.34 \%$ (control) and $0.03 \%$ (unsupplemented) dietary calcium (Ca) for 10 weeks at $27.0 \pm 1.4^{\circ} \mathrm{C}$. Final body weight, condition factor and hepatosomatic index were not affected by dietary $\mathrm{Ca}$ in both species. Feed efficiency in black sea bream was almost same between two dietary groups, however, feed efficiency in red sea bream fed the Ca unsupplemented diet were slightly lower than that in fish fed the control diet. Dietary Ca levels did not affect blood characteristics of red sea bream and black sea bream. In both species $\mathrm{Ca}$ and other mineral contents of the bone were independent of a dietary $\mathrm{Ca}$ supplement except that $\mathrm{K}$ and $\mathrm{Mn}$ contents of red sea bream fed the $\mathrm{Ca}$ unsupplemented diet were significantly lower than those in the control. It appeared that Ca supplements to the purified diets are not necessary in juvenile red sea bream and black sea bream.
\end{abstract}

\section{INTRODUCTION}

In the previous studies we observed that red sea bream with initial body weight of $11.5 \mathrm{~g}$ and black sea bream with initial body weight of $8.0 \mathrm{~g}$ did not require a dietary calcium (Ca) supplement (Hossain and Furuichi, 1999a, b). However, a dietary Ca supplement was necessary in tiger puffer, redlip mullet and Japanese flounder with initial body weight of $1.6 \mathrm{~g}, 0.6 \mathrm{~g}$ and $0.7 \mathrm{~g}$, respectively (Hossain and Furuichi, 1998, 2000a, b). From those results it was considered that the unnecessary of Ca supplement to the diet detected in red sea bream and black sea bream might have been due to the larger initial body weight. Satoh et al. (1987) observed that whole body mineral contents of rainbow trout did not change after body weight reached $2.0 \mathrm{~g}$, and recommended to conduct the feeding experiment for mineral study with fish less than $2.0 \mathrm{~g}$ body weight. The present study was conducted to investigate whether dietary Ca supplements were necessary to juvenile red sea bream and black sea bream.

\footnotetext{
* Laboratory of Fish Production Technology, Division of Fish Production Technology, Department of Animal and Marine Bioresource Science, Graduate School of Bioresource and Bioenvironmental Sciences, Kyushu University. Corresponding author. Present address: Marine Fisheries and Technology Station, Bangladesh Fisheries Research Institute, Cox's Bazar-4700, Bangladesh. E-mail: m_amzad_hossain@hotmail.com.
} 


\section{MATERIALS AND METHODS}

\section{Experimental Diets and Feeding Regime}

Two purified diets with or without Ca supplement were formulated (Table 1). Vitamin-free milk casein, dextrin and $\alpha$-starch (gelatinized potato starch), and pollack liver oil were used as protein, digestible carbohydrate and lipid sources, respectively. A mixture of vitamins (Halver, 1957) was added equally to the diets. The diet containing

Table 1. Composition of the experimental diets for red sea bream and black sea bream

\begin{tabular}{lcc}
\hline Diet & Control & No Ca supplement \\
\hline Ingredient (\%) & & \\
Casein & 50 & 50 \\
Amino acid mix.*1 & 4 & 4 \\
$\alpha$-Potato starch & 7 & 7 \\
Dextrin & 10 & 10 \\
Pollack liver oil & 10 & 10 \\
Vitamin mix.*2 & 3 & 3 \\
Mineral mix.*3 & 6 & 6 \\
Carboxymethylcellulose & 4 & 4 \\
Ca-lactate & 2.308 & - \\
$\alpha-C e l l u l o s e$ & 3.692 & 6 \\
\hline
\end{tabular}

*1 Amino acid mixture (g/kg diet): arginine $\cdot \mathrm{HCl}, 10$; alanine, 10 ; glycine, 10 ; aspartate $\cdot \mathrm{Na}, 10$.

*2 Vitamin mixture (Halver, 1957).

*3 Mineral mixture (mg/kg diet): $\mathrm{KCl}, 3840 ; \mathrm{MgSO}_{4} \cdot 5 \mathrm{H}_{2} \mathrm{O}, 4080$; $\mathrm{NaH}_{2} \mathrm{PO}_{4} \cdot 2 \mathrm{H}_{2} \mathrm{O}, 34260 ; \mathrm{Fe}$-citrate, $1200 ; \mathrm{AlCl}_{3} \cdot 6 \mathrm{H}_{2} \mathrm{O}, 45$; $\mathrm{ZnSO}_{4} \cdot 7 \mathrm{H}_{2} \mathrm{O}, 132 ; \mathrm{MnSO}_{4} \cdot 5 \mathrm{H}_{2} \mathrm{O}, 877 ; \mathrm{CuCl}, 7.9 ; \mathrm{KI}, 1.9 ; \mathrm{CoCl}_{2} \cdot$ $6 \mathrm{H}_{2} \mathrm{O}, 0.7$.

Table 2. Proximate and mineral compositions of the experimental diets for red sea bream and black sea bream

\begin{tabular}{|c|c|c|}
\hline Diet & Control & No Ca supplement \\
\hline \multicolumn{3}{|c|}{ Proximate composition (\% dm)* } \\
\hline Moisture & 20.9 & 21.5 \\
\hline Crude protein & 51.3 & 52.0 \\
\hline Crude lipid & 9.1 & 9.3 \\
\hline Crude ash & 5.1 & 5.0 \\
\hline \multicolumn{3}{|c|}{ Mineral composition (dm) } \\
\hline $\mathrm{Ca}(\%)$ & 0.34 & 0.03 \\
\hline $\mathrm{P}(\%)$ & 1.00 & 1.05 \\
\hline $\mathrm{K}(\%)$ & 0.19 & 0.18 \\
\hline $\operatorname{Mg}(\mu \mathrm{g} / \mathrm{g})$ & 400 & 370 \\
\hline $\mathrm{Fe}(\mu \mathrm{g} / \mathrm{g})$ & 280 & 270 \\
\hline $\mathrm{Zn}(\mu \mathrm{g} / \mathrm{g})$ & 48 & 52 \\
\hline $\operatorname{Mn}(\mu \mathrm{g} / \mathrm{g})$ & 16 & 16 \\
\hline $\mathrm{Cu}(\mu \mathrm{g} / \mathrm{g})$ & 11 & 12 \\
\hline
\end{tabular}

* dm, dry matter. 
0.3\% Ca from Ca-lactate was control. The method of diet preparation was the same as that reported previously (Hossain and Furuichi, 1999b). The proximate and mineral compositions of the diets are shown in Table 2.

\section{Fish and Rearing Methods}

Juvenile red sea bream and black sea bream were accustomed to a casein diet in $100-\ell$ circular tanks for 2 weeks before the experiments. At the start of the experiment, the fish of each species were weighed individually, selected, and distributed to four tanks (duplicate per treatment) in such a manner that average body weight and size variation of fish in each tank were similar. The number of fish in a tank was 30 (average body weight $1.4 \mathrm{~g}$ ) for red sea bream and 40 (average body weight $0.5 \mathrm{~g}$ ) for black sea bream. The fish were reared for 10 weeks, during which the experimental diets were fed twice a day at 09:00 and 15:30h. Diets were offered to the fish until satiation. Each tank was provided with adequate oxygen by aeration and continuous sea water (2-3 $\ell / \mathrm{min})$ supplies. Water temperature was $27.0 \pm 1.4^{\circ} \mathrm{C}$ during the rearing period. A Ca level in the rearing water was around $400 \mathrm{mg} / \mathrm{l}$. Other rearing conditions and methods were the same as those reported previously (Hossain and Furuichi, 1999b).

\section{Sampling and Analysis}

At the end of the feeding trial, the body weight and body length of the fish were measured individually to calculate the condition factor. Blood samples were collected from the cuvierian duct with a $1 \mathrm{ml}$ heparinized syringe. Each liver was weighed to calculate the hepatosomatic index. Pooled samples of all the livers and whole carcasses were stored at $-20^{\circ} \mathrm{C}$ for chemical analysis and bone collection, respectively.

Analyses of blood, bone and diet samples were the same as those described previously (Hossain and Furuichi, 1999b).

Student's T-test was applied to determine the significance in difference between the treatment means $(P<0.05)$.

\section{RESULTS}

\section{Red Sea Bream}

Growth performances and feed utilization of red sea bream are shown in Table 3. The survival rates at the end of the experiment were $96.7 \%$ and $100 \%$ in fish fed the control and the Ca unsupplemented diets, respectively. No significant difference was observed in the final body weight between two treatment groups. Feed efficiency in fish fed the Ca unsupplemented diet was slightly lower than that in fish fed the control diet. Condition factor and hepatosomatic index were not affected by dietary Ca levels. Hematocrit values, hemoglobin and plasma protein contents were similar in both dietary groups (Table 4).

The results of bone analyses are presented in Table 5. Bone lipid and ash contents were similar in both groups. $\mathrm{Ca}$ and $\mathrm{P}$ contents of the bone appeared to be independent of a dietary Ca supplement. A deletion of supplemental $\mathrm{Ca}$ from the diet did not affect the bone $\mathrm{Mg}, \mathrm{Fe}, \mathrm{Zn}$ and $\mathrm{Cu}$ contents. However, lower bone $\mathrm{K}$ and $\mathrm{Mn}$ contents were detected in fish fed the $\mathrm{Ca}$ unsupplemented diet compared to the control diet. 
Table 3. Growth and feed utilization of red sea bream and black sea bream fed the experimental diets with or without Ca supplement

\begin{tabular}{lcc}
\hline Diet & Control & No Ca supplement \\
\hline Red sea bream & & \\
Av. body wt. (g) & & \\
Initial & 1.42 & 1.42 \\
Final*1 & 14.4 & 13.9 \\
Weight gain (\%) & 910 & 880 \\
Feed efficiency (\%) & 83.4 & 75.7 \\
Condition factor*1,2 & 3.28 & 3.37 \\
HSI*1,3 & 2.24 & 2.34 \\
Survival rate (\%) & 96.7 & 100 \\
\hline Black sea bream & & \\
Av. body wt. (g) & & \\
Initial & 0.54 & 0.54 \\
Final & & \\
Weight gain (\%) & 12.6 & 12.3 \\
Feed efficiency (\%) & 2230 & 2180 \\
Condition factor*1,2 & 104.5 & 105.6 \\
HSI*1,3 & 2.87 & 2.82 \\
Survival rate (\%) & 1.84 & 1.85 \\
\hline
\end{tabular}

*1 No significant difference $(P>0.05)$.

*2 Body weight $(\mathrm{g}) \times 100 /(\text { body length in } \mathrm{cm})^{3}$.

${ }^{* 3}$ Hepatosomatic index: Liver weight $(g) \times 100 /$ body weight $(g)$.

Table 4. Hematocrit, hemoglobin and plasma protein of red sea bream and black sea bream fed the experimental diets with or without $\mathrm{Ca}$ supplement

\begin{tabular}{lrc}
\hline Diet & Control & No Ca supplement \\
\hline Red sea bream & & \\
Hematocrit $(\%)^{*}$ & 38.5 & 38.0 \\
Hemoglobin $(\mathrm{g} / 100 \mathrm{ml})^{*}$ & 3.3 & 3.4 \\
Plasma protein $(\mathrm{g} / 100 \mathrm{ml})^{*}$ & 4.4 & 3.9 \\
\hline Black sea bream & & \\
Hematocrit $(\%)^{*}$ & 38.0 & 38.0 \\
Hemoglobin $(\mathrm{g} / 100 \mathrm{ml})^{*}$ & 8.6 & 8.9 \\
Plasma protein $(\mathrm{g} / 100 \mathrm{ml})^{*}$ & 5.4 & 5.5 \\
\hline
\end{tabular}

* No significant difference $(P>0.05 ; n=10)$.

\section{Black Sea Bream}

Survivals of black sea bream were $92.5 \%$ and $96.3 \%$ in fish fed the control diet and $\mathrm{Ca}$ unsupplemented diet, respectively (Table 3). Final body weight was not statistically different between two dietary groups. Feed efficiency, condition factor and hepatosomatic index were not affected by a Ca unsupplementation to the diet. Effects of a deletion of dietary Ca were not observed in hematocrit, hemoglobin and plasma protein 
Table 5. Lipid, ash, and mineral composition of the bone of red sea bream and black sea bream fed the experimental diets with or without Ca supplement*1

\begin{tabular}{|c|c|c|}
\hline Diet & Control & No Ca supplement \\
\hline \multicolumn{3}{|l|}{ Red sea bream } \\
\hline Crude lipid (\%) & 20.5 & 20.3 \\
\hline Crude ash (\%) & 55.8 & 56.0 \\
\hline $\mathrm{Ca}(\%)$ & 27.3 & 27.4 \\
\hline $\mathrm{P}(\%)$ & 10.5 & 10.6 \\
\hline $\operatorname{Mg}(\%)$ & 0.44 & 0.42 \\
\hline $\mathrm{K}(\mu \mathrm{g} / \mathrm{g})$ & 58 & $39 * 2$ \\
\hline $\mathrm{Fe}(\mu \mathrm{g} / \mathrm{g})$ & 208 & 200 \\
\hline $\mathrm{Zn}(\mu \mathrm{g} / \mathrm{g})$ & 106 & 104 \\
\hline $\operatorname{Mn}(\mu \mathrm{g} / \mathrm{g})$ & 48 & $38^{* 2}$ \\
\hline $\mathrm{Cu}(\mu \mathrm{g} / \mathrm{g})$ & 7.1 & 6.7 \\
\hline \multicolumn{3}{|l|}{ Black sea bream } \\
\hline Crude lipid (\%) & 19.2 & 19.0 \\
\hline Crude ash (\%) & 62.0 & 63.0 \\
\hline $\mathrm{Ca}(\%)$ & 25.6 & 25.5 \\
\hline P (\%) & 10.2 & 10.3 \\
\hline $\operatorname{Mg}(\%)$ & 0.67 & 0.63 \\
\hline $\mathrm{K}(\mu \mathrm{g} / \mathrm{g})$ & 82.8 & 90.5 \\
\hline $\mathrm{Fe}(\mu \mathrm{g} / \mathrm{g})$ & 200 & 198 \\
\hline $\operatorname{Zn}(\mu \mathrm{g} / \mathrm{g})$ & 155 & 159 \\
\hline $\operatorname{Mn}(\mu \mathrm{g} / \mathrm{g})$ & 39.0 & 40.3 \\
\hline $\mathrm{Cu}(\mu \mathrm{g} / \mathrm{g})$ & 7.9 & 7.3 \\
\hline
\end{tabular}

*1 Dry matter basis.

*2 Significant difference $(P<0.05)$.

values of the fish (Table 4). Ash, lipid and mineral contents of the bone were identical between the control and $\mathrm{Ca}$ unsupplemented diet groups (Table 5).

\section{DISCUSSION}

Since the growth of fish was almost identical between the control and $\mathrm{Ca}$ unsupplemented diets in both red sea bream and black sea bream, these two fish species may absorb adequate $\mathrm{Ca}$ from sea water for their metabolic requirements. Previous studies showed that dietary Ca supplements were not necessary for relatively larger sized red sea bream and black sea bream (Hossain and Furuichi, 1999a, b). The present study is further confirmation of the previous studies, and revealed that these two species did not need a Ca supplement to a purified diet irrespective of the fish size. The similarity in $\mathrm{Ca}$ requirements in these two species may be for the reason that both species belong to the same family and have a similar food habit. The present results also are in accordance with a well accepted concept that fish have a capability to absorb $\mathrm{Ca}$ from surrounding water and a dietary supplement may not be necessary (Love, 1980). Sakamoto and Yone (1976) also reported that a Ca supplement was dispensable in a purified diet for red sea bream. It appeared from the growth, hematological, and liver and bone mineralization 
data in the present study that Ca absorption from sea water might be adequate for red sea bream and black sea bream. In the study with radio isotope, we observed that red sea bream (average body weight $0.7 \mathrm{~g}$ ) and black sea bream (average body weight $0.8 \mathrm{~g}$ ) had increased the absorption of ${ }^{45} \mathrm{Ca}$ from sea water when Ca was deleted from a purified diet and overall absorption of $\mathrm{Ca}$ was very high in both species (Hossain and Furuichi: Fish. Res. Lab., Kyushu Univ., unpubl. data). Sakamoto (1981) also reported that the absorption of radioactive $\mathrm{Ca}$ in red sea bream increased with the decrease of dietary Ca levels. Therefore, the present investigation suggests that a dietary Ca supplement may not be necessary for red sea bream and black sea bream. On the other hand, environmental $\mathrm{Ca}$ was found not to be sufficiently available in tiger puffer, redlip mullet and Japanese flounder (Furuichi et al., 1997, 1999; Hossain and Furuichi, 1998, 2000a, b). Therefore, further investigations are important to find out why Ca absorption from sea water is different among marine fish species.

\section{ACKNOWLEDGEMENTS}

We would like to express our sincere thanks to Dr. Seiichi Matsui and Dr. Takao Yoshimatsu for their kind help in conducting this research. This is the contribution no. 250 from Fishery Research Laboratory, Kyushu University.

\section{REFERENCES}

Furuichi, M., Y. Furusho, M. A. Hossain, S. Matsui and R. Azuma 1997 Essentiality of Ca supplement to white fish meal diet for tiger puffer. J. Fac. Agr., Kyushu Univ., 42: 77-85

Furuichi, M., M. A. Hossain and S. Matsui 1999 Effect of dietary supplemental calcium levels on growth and mineral composition of bone in tiger puffer. Suisanzoshoku, 47: 409-413

Halver, J. E. 1957 Nutrition of salmonid fishes. II. Water-soluble vitamin requirements of chinook salmon. J. Nutr., 62: 225-243

Hossain, M. A. and M. Furuichi 1998 Availability of environmental and dietary calcium in tiger puffer. Aquacult. Int., 6: 121-132

Hossain, M. A. and M. Furuichi 1999a Effect of deletion of calcium supplement from purified diet on growth and bone mineralization in red sea bream. J. Fac. Agr., Kyushu Univ., 44: 91-97

Hossain, M. A. and M. Furuichi 1999b Necessity of dietary calcium supplement in black sea bream. Fisheries Sci., 65: 893-897

Hossain, M. A. and M. Furuichi $2000 \mathrm{a}$ Essentiality of dietary calcium supplement in redlip mullet Liza haematocheila. Aquacult. Nutr., 6: 33-38

Hossain, M. A. and M. Furuichi 2000b Necessity of calcium supplement to the diet of Japanese flounder. Fisheries Sci., 66: $660-664$

Love, R. M. 1980 The Chemical Biology of Fishes, Vol. 2, Academic Press, New York

Sakamoto, S. 1981 Requirements and deficiency symptoms of dietary minerals in red sea bream. Rep. Fish. Res. Lab., Kyushu Univ., 5: 1-99

Sakamoto, S. and Y. Yone 1976 Requirement of red sea bream for dietary Ca. Rep. Fish. Res. Lab., Kyushu Univ., 3: 59-64

Satoh, S., T. Takeuchi and T. Watanabe 1987 Changes of mineral compositions in whole body of rainbow trout during growing stages. Nippon Suisan Gakkaishi, 53: 273-279 